\title{
Ribka Tjiptaning's Provocative Speaking Action in Social Media: Forensic Linguistic Study
}

\author{
Sarifuddin Kamaruddin ${ }^{1 *}$, Tadjuddin Maknun ${ }^{1}$, Ery Iswary ${ }^{1}$ \\ ${ }^{1}$ Linguistic Faculty, Hasanuddin University, Indonesia \\ *Korespondensi: syarifuddinkamaruddin66@gmail.com
}

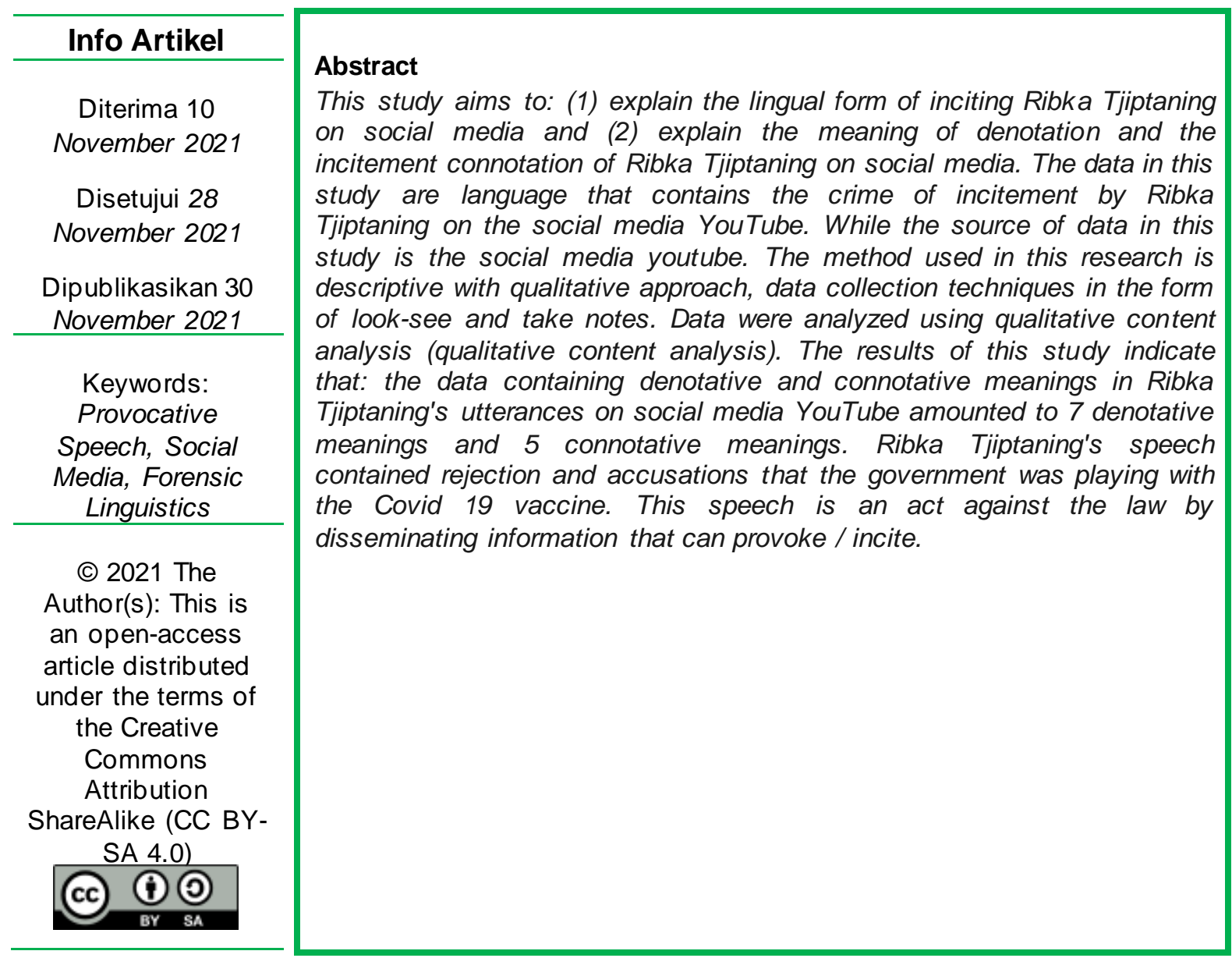

\section{Pendahuluan}

Technological advancements significantly impact how language is used, particularly in social media, communication, information, and entertainment. The ease with which technology may be employed as a communication to ol allows for the erasure of spatial and temporal barriers, allowing for conversation even when someone is adrift over great distances in a short period of time. 
A person may communicate with a large number of individuals simultaneously due to technological advancements. People are becoming increasingly reliant on social media platforms such as youtobe, facebook, twitter, path, whatsapp, blackberry messager, and line to obtain information swiftly. Numerous social media platforms offer varying degrees of communication ease by incorporating diverse elements (Rahman et al., 2019).

On the other side, information and communication technology has a detrimental influence, resulting in the rise of new crimes committed via internet sites, dubbed cyber crime. This has an effect on social life in ways that are inconsistent with the role of language, such as hate speech, incitement/provocation, defamation, fake news, violence, and sexual harassment (Hamuddin et al., 2020).

The use of social media must be accompanied with wisdom while talking on social media, since the possibility for breaching the law on social media, particularly in the interaction area, is quite vulnerable. The language employed as a communication tool frequently encounters semantic and pragmatic mistakes as a result of its function. Language errors or impoliteness can pull speakers into the sphere of the law. Incitement/provocation is one of the illegal offenses that occurs when information is misused on social media. Each year, there are instances of incitement on social media. This demonstrates that language may be used to establish a crime through the use of forensic linguistic research. Linguists employ linguistics (linguistics) to assist in the resolution of legal matters (Hamuddin et al., 2019).

According to McMenamin (2002), forensic linguistics is the scientific study of language used for forensic reasons and legal declarations. Forensic linguistics can assist in proving a judicial case. Grammar theory, conversation theory, discourse analysis, cognitive linguistics, speech acts, and descriptive linguistic theories and methods such as phonetics and phonology, lexis, syntax, semantics, pragmatics, discourse, and text analysis are all examples of applied linguistic theories.

According to Olsson (2004), forensic linguistics is the application of language concepts to legal issues. That instance, many forensic linguistics applications address language evidence utilized in legal procedures. For instance, the inspection of audio recordings of conversations, legislative language, courtroom language, police questioning of suspects, and so on.

This paper examines the case of Ribka Tjiptaning's incitement/provocation on social media. Incitement/provocation speeches were investigated utilizing forensic linguistic theory as a grand theory in conjunction with semantic research (meaning denotation and connotation). The analysis's findings were compared to the Criminal Code in order to determine the legal implications of initiating/provocation on social media.

\section{Theoretical Basis}

According to Olsson (2004), forensic linguistics is the study of the relationship between language, crime, and the law, which encompasses law enforcement, legal issues, legislation, disputes or legal processes, and even disputes that may involve multiple violations of the law in the pursuit of a legal settlement. Forensic linguistics is concerned with the application of lingu istic theories to a linguistic occurrence 
involving a legal procedure (Subyantoro, 2019). Thus, forensic linguistics is a branch of linguistics concerned with the examination of legal infractions. According to Saletovic and Kisicek (Santoso, 2013), forensic linguistics is a subfield of applied linguistics concerned with the study of interactions, language, crime, and law. That is, forensic linguistics bridges the divide between linguistics and law.

Semantics is one of the branches of science that is used to research linguistics that is concerned with meaning; meaning is inextricably linked to the level of language, since meaning is a significant subject of study. According to Kridalaksana (2011), semantics is a subset of language structure concerned with the meaning of expressions and the structure of the meaning of speech. The meaning of a conversation refers to the discussion's aim, the impact of linguistic units on perceptions, as well as individual or group behavior. Tarigan (2014) defines semantics as the study of symbols or signs that communicate meaning, their connection to one another, and their impact on persons and society. As a result, semantics is inextricably linked to the meaning employed by the speaking community.

Additionally, the semantic study technique can have a behavioral component; the behavioral part studies the meaning of speech occurrences in specific settings (speech situations). A speech act is the smallest unit of speech that conveys the whole meaning of the entire speech event that occurs in a speaking scenario Atfalusoleh (2017). This indicates that in addition to the word or lexeme, the context of the circumstances and conditions at the time the word is employed is examined in the study of meaning. This study analyzes the meaning of Ribka Tjiptaning's social media discourse using denotative and connotative meanings.

The denotative meaning of a term is the connotation derived from a simple, basic, and direct identification. According to Chaer (2014), denotative meaning is essentially synonymous with referential meaning since it is frequently defined as meaning that is consistent with the findings of observations based on sight, smell, hearing, emotion, or other experiences. Denotative meaning is also sometimes used interchangeably with denotative. According to the KBBI (2018: 45), denotation is the meaning of a word or set of words that is based on a simple designation of something that is not a part of the language or is based on specific rules and is objective.

Connotative meaning is an aspect of the meaning of a word or set of words that is based on the speaker's (writer's) or listener's sentiments or ideas (reader), The connotative meaning manifests itself in use and rhetoric and has acquired extra sentiments in the shape of taste values, specific emotions, and often surprising biases. As a result, the definition of connotation is uncommon in the dictionaries of some languages. The connotative meaning of a word must be acquired and mastered via linguistic experience and application. Certain connotations have been incorporated into the dictionary if their meaning has developed into a generic connotation and generic connotation.

The denotative and connotative meanings of words are inextricably linked. This is also stated by Atfalusoleh (2017) in his journal titled "Reaction Time of Semantic Unrelated Tasks of Arabic Language Lexical Units: A Cognitive Study," in which he asserts that these denotative and connotative meanings are connected and have sound concepts in either the native or foreign language. The notation or 
reference establishes the link between denotation and connotation. Both have identical or almost identical notation, but one begins with de- and the other with co. The suffix de indicates that the notation is fixed and natural in its current state, whereas the prefix ko suggests that "with others, there is further addition" to the notation in question. Thus, denotation is the original natural meaning that occurs first, the one that is understood from the start, the meaning in its entirety.

Not only are crimes unlawful acts, but a person can also be penalized for inviting, ordering/asking, influencing, or inciting others to commit crimes (crimes against others), which is referred to as sedition. Tiersma and Solan (Sholihatin, 2019). Article 160 of the Criminal Code regulates the conduct of inciting as follows:

"Whoever incites to commit a criminal act in public, verbally or in writing, commits violence against a public authority, or fails to comply with both the provisions of the law and the order of office granted in accordance with the provisions of the law, faces a maximum imprisonment of six years or a maximum fine of four thousand five hundred rupiah."

Furthermore, Article 161 paragraph (1) of the Criminal Code reads:

Anyone who broadcasts, displays, or posts a writing in public that incites to commit a criminal act, opposes the general authority with violence, or opposes something else as mentioned in the article above, with the intent that the content that incites is known or becomes more known by the public, shall face a maximum penalty of four years in prison or a maximum fine of four thousand five hundred rupiahs.

Language crimes are often committed on social media. According to Van Dijk (Nasrullah, 2015), social media is a type of media platform centered on users who promote activities and cooperation. Thus, social media may be viewed as an online medium (facilitator) that strengthen s both the user-user interaction and the societal link. Meanwhile, (Suhariyanto, 2011) defines social media as an online medium that enables users to quickly adapt, share, and produce material. Due to the diversity of social media platforms, individuals may readily access and use them for social contact.

Social media is referred to as online social networking due to its social strength, which significantly affects how public opinion develops in society. The presence of social media is fundamentally similar to the existence and operation of computers. Recognition, communication, and collaboration may be compared to how computers function, which are also part of a system, just as persons and society are part of a system (Suhariyanto, 2011)

\section{Methodology}

This is a descriptive study using a qualitative technique. Ribka Tjiptaning's vocabulary in her provocative speech acts on the social media platform YouTube serves as the data for this research. While the social media platform YouTube serves as the data source for this study. A look-see and note-taking strategy was utilized to obtain data. Qualitative content analysis is the data analysis approach employed. 


\section{Discussion}

Ribka Tjiptaning is a member of the Indonesian House of Representatives representing the Indonesian Democratic Party of Struggle (PDIP). She continues to have reservations about the COVID-19 vaccine based on her experience administering a number of other vaccines that have been known to paralyze people to death.

\section{Source: https://youtu.be/DFV9Et9EGnM}

\section{“Reject Vaccine, Better to Pay Rp. 5 million"}

"I still do not wish to get vaccinated, nor do I believe that individuals who reach the age of 63 should be vaccinated." I'm already 63 years old here. Wants of all ages are still possible. For instance, even if I live in DKI, am I entitled to all of my children and grandchildren? What is it referred to as? 5 million dollar fine? Allow me to pay. I'm selling a cake automobile. How come biopharmaceuticals continue to assert the absence of a third clinical study and so forth? This, Minister, is my experience. This is what I'm going to say again in this meeting, all right? The polio vaccination paralyzed Sukabumi's withering for anti-polio. Make your way on elephant legs. In Majalaya 12, 12 people perished because it was rejected in India, in Africa, and in Indonesia with 1.3 trillion dollars when I was head of the commission. That I recall vividly; do not tamper with this vaccination. Take no chances. I'm the first to admit that I am anti-vaccine. If human rights need that, Iol! Violations against human rights. That is not the way to charge. I keep questioning, Which one is the free one, the one that is claimed to be open to all people? There are four to five distinct types of persons. Some are priced at 584,000 rupiah, while others are priced at 292,000 rupiah, 116,000 rupiah, and 2,100,000 rupiah s. If the poor, it must be inexpensive. Now, people, this is a RAPID problem; this is a SWAB problem. As I stated yesterday, Mrs. Peni, there is no maximum retail price yet. There is a private hospital, Abdi Waluyo, and I inquired as to the cost of the doctor's SWAB for a single day. That's six million and a half, but three million and a half if the result is three days. Loh, is this the standard throughout the examination, or is it due to the money? I was at another clinic yesterday, one with a population of 900,000 . Saturday is a downer. Rather than being named in the DPR, it will become a project if my name is included; do not dare. Since last March, I have stated at this conference that once COVID is established, it inevitably results in the sale of pharmaceuticals and vaccines. Following that, yes, as now is not the time for PPE. After this, there is a great deal of medication. Following the medicine, this is now an economist, a minister. Come on, it should be the responsibility of the Deputy Minister of State-Owned Enterprises. This is a revision. As you are well aware, it has been designed in this manner; the health is for trading. I've already contacted Adinda the Minister. To be sure, the state cannot transact commerce with its citizens. Not at all. You cannot, for whatever reason."

\subsection{Denotative Meaning}

Suwandi (2008: 80 ) defines denotative meaning as the meaning of a term that is based on a direct, plain, and straightforward designation; denotative meaning is sometimes referred to as the fundamental or genuine meaning. The following demonstrates the denotative significance of Ribka Tjiptaning's YouTube social media speech: 
Data (1)

The term vaccination has a connotative connotation. In $\mathrm{KBBI}$, the term "vaccine" refers to a weakened disease germ used for immunization. The term vaccine in the statement has a legitimate meaning and is consistent with the sentence's context, which demonstrates a refusal to get immunizations. Thus, the usage of the term vaccination is consistent with the sentence's context.

Data (2)

The term age has a denotative sense in the preceding statement. The word age has a significant meaning in this statement since it refers to what is discussed in the text. The report explains that vaccination is safe for people of all ages. Thus, the word age is suitable in the context of the phrase.

Data (3)

The term clinical trials has a denotative connotation in the preceding statement. However, clinical trials have a precise definition: they are tests of a drug's biological activity (particularly its effectiveness and safety) conducted directly on humans. The statement indicates that the biopharmaceutical business has not yet undertaken a third round of testing on the vaccination medication. Thus, the term clinical trials is appropriate in light of the sentence's context.

Data (4)

The term "experience" in the preceding statement has a denotative connotation. The text's use of the term "experience" is contextual. Experience equates to expertise (felt, lived, endured, and so on). The word experience in the preceding line indicates that the polio vaccination resulted in paralysis and elephantiasis in Sukabumi. Thus, the term "experience" is suitable in light of the discussion's context.

Data (5)

The term "violation" in the preceding sentence has a denotative connotation. The term "violation" refers to the act of violating. In the statement, the term "violation" refers to the act of breaching human rights (Human Rights) in the situation of vaccination compulsion. The term "violation" is used in line with the discussion's context.

Data (6)

The term "violation" in the preceding sentence has a denotative connotation. The term "violation" refers to the act of violating. In the statement, the term "violation" refers to the act of breaching human rights (Human Rights) in the situation of vaccination compulsion. The term "violation" is used in line with the discussion's context.

Data (7)

The term "hospital" has a denotative connotation. The term "hospital" refers to a structure used to house and offer health care for a variety of health concerns. In this statement, the word Abdi Waluyo hospital refers to the facility that provides 
and administers the SWAB exam. The term "hospital" is appropriate given the context of the conversation.

\subsection{Connotative Meaning}

The connotative meaning is the meaning that has been enhanced by the inclusion of certain sentiments, emotions, values, and experiences that are different and unexpected (Parera, 2004). The following evidence supports the connotative meaning included in Ribka Tjiptaning's YouTube social media speech:

Data (1)

Although my clause 63 does not have the literal meaning, it already contains a connotative meaning. My clause 63 actually means that I am already 63 years old. The phrase I am already 63 does not include the statement's true meaning because if it did, the meaning would be confusing. Given that the context of the preceding statement refers to the number 63, it can be taken as age. Age refers to the period of one's life, and hence the statement indicates that the period of my existence is 63 years. Thus, the right writing is as follows:

1 (a) "I still don't want to be vaccinated even though I can be vaccinated until I am 63. I'm 63 years old now."

\section{Data (2)}

The term "elephant's foot" carries a connotative connotation. The term "elephant's foot" refers to the elephant's animal leg. The term elephantiasis brings the notion of beriberi sickness. The usage of the term elephantiasis in the preceding statement distorts the meaning of the sentence because it refers to disease kinds rather than animals. As a result, the proper writing is as follows:

2 (a) Sukabumi was even crippled by the polio vaccination for anti-polio. Persist with the beriberi sickness. In Majalaya 12, 12 people perished because it was rejected in India, in Africa, and in Indonesia with 1.3 trillion dollars when I was head of the commission. That I recall vividly; do not tamper with this vaccination. Take no chances!"

Data (3)

The term "good economist" carries a connotative connotation. The term "expert economist" refers to a person who is exceptional/expert in the subject of economics. This word carries a connotation, as an economist is defined as a person who manipulates money for personal gain. This term implies that the minister is engaging in financial speculation for personal or group gain by selling medications and vaccinations to the public. As a result, the proper writing is as follows:

3 (a) Since March, I have stated at this meeting that if Covid is established, it would end up selling pharmaceuticals and vaccines. Following that, well, now is not the time for PPE. After this, there is a great deal of medication. Following the medication, this is now money-laundering for the minister's advantage."

Data (4) 
Because the sentence above does not convey the true meaning, it has the connotation of drug sales. However, the true definition of the term "selling pharmaceuticals" is "selling the chemicals necessary to heal a sickness." According to the context of the preceding line, when the Covid 19 epidemic struck Indonesia, the government sought revenues from the selling of medications and vaccinations. As a result, the proper writing is as follows:

4 (a) Since March, I've stated at this meeting that once Covid is established, it would seek profit through the sale of pharmaceuticals and vaccines. Following that, well, because this is not the time for personal protective equipment".

Data (5)

The preceding statement has a connotative meaning since it omits the literal meaning. The sentence's true meaning is that the state may not transact business with its citizens. Organizations with the highest legal authority and who are obeyed by the populace are not permitted to conduct commerce with a country's population. The notion that the state cannot engage in commerce with its citizens implies that the state should abstain from profiteering on behalf of its citizens. As a result, the proper writing is as follows:

5 (a) "Well, Organizations in an area that have the highest legal power and are obeyed by the people may not conduct trade business with residents of a country.

\section{Conclusion}

The data analysis revealed that Ribka Tjiptaning's social media statements comprised seven denotative and five connotative meanings. This statement is considered a form of provocative / incitement because it has the potential to persuade people to reject the vaccination program that the government is implementing to contain the spread of the Covid-19 virus, and thus can be classified as committing an unlawful act by spreading information that has the potential to provoke.

\section{References}

Atfalusoleh, S. (2017). Analisi Makna Denotatif dan Konotatif Teks Biografi Presiden Soekarno dan Impilkasinya sebagai Bahan Ajar di SMP Kelas VIII. Publikasi IImiah.

Chaer, A. (2014). Linguistik Umum Edisi Revisi. Rineka Cipta.

Hamuddin, B., Rahman, F., Pammu, A., Sanusi Baso, Y., \& Derin, T. (2020). Cyberbullying Among EFL Students'blogging Activities: Motives And Proposed Solutions. Teaching English with Technology, 20(2), 3-20.

Hamuddin, B., Syahdan, S., Rahman, F., Rianita, D., \& Derin, T. (2019). Do They Truly Intend to Harm Their Friends?: The Motives Beyond Cyberbullying among University Students. International Journal of Cyber Behavior, Psychology and Learning (IJCBPL), 9(4), 32-44.

Kridalaksana, H. (2011). Kamus Linguistik. Gramedia Pustaka Utama.

McMenamin. (2002). Forensic Stylistics. Elsevier.

Olsson, J. (2004). Forensic Linguistics (second edition). Continuum International Publishing Group. 
Parera. (2004). Teori Semantik. Erlangga Group.

Rahman, F., Abbas, A., \& Hasyim, M. (2019). Facebook Group as Media of Learning Writing in ESP Context: A Case Study at Hasanuddin University. Asian EFL Journal Research Articles, 26(6.1), 153-167.

Santoso, I. (2013). Mengenal Linguistik Forensik: Linguis sebagai Saksi Ahli. Universitas Negeri Yogyakarta.

Sholihatin, E. (2019). Linguistik Forensik dan Kejahatan Berbahasa. Pustaka Pelajar.

Subyantoro. (2019). Linguistik Forensik: Sumbangsih Kajian Bahasa dalam Penegakan Hukum. ADIL Indonesia Jurnal, 1(1), 36-50.

Suhariyanto. (2011). Komunikasi dalam Media Massa. Simbiosa Rekatama Media. Tarigan. (2014). Pengajaran Semantik. Angkasa. 